Agro-Science Journal of Tropical Agriculture, Food, Environment and Extension Volume 18 Number 2 (May 2019) pp. 20-25

ISSN 1119-7455

\title{
DOUBLE HURDLE MODELLING APPROACH TO LOCAL RICE CONSUMPTION IN IKWUANO LOCAL GOVERNMENT AREA OF ABIA STATE, NIGERIA
}

\author{
${ }^{1}$ Onya, S.C., ${ }^{1}$ Okezie, C.A. and ${ }^{2}$ Ejiba, I.V. \\ ${ }^{1}$ Department of Agricultural Economics, Michael Okpara University of Agriculture, \\ Umudike, Abia State, Nigeria \\ ${ }^{2}$ Department of Agricultural Economics, University of Ibadan, Ibadan, Nigeria \\ Corresponding author's email: simeononya@yahoo.com
}

\begin{abstract}
This study analysed the preference and expenditure decision on local rice of rural households in Ikwuano Local Government Area of Abia State, Nigeria. A two-stage systematic sampling technique was used in selecting 150 respondents for the study. The households were stratified based on the income levels. Data collected were analysed using descriptive statistics (such as percentages and means) and the double hurdle modeling approach. The result of the descriptive statistics showed that majority (64\%) of the respondents were female, $76 \%$ were married, $94.67 \%$ were below the age of 55 years with a mean age of 41.09 years. Majority (40\%) had secondary education among the household heads with a mean years spent in school of 10.56 years while majority (40\%) among the spouse had primary education with a mean years spent in school of 8.69 years. The mean household size was about 6 persons. The result of the income distribution of the households showed that majority (52\%) of the respondents earn between $\$ 20,000-40,000$ per month while the result of the preference for rice showed that $56 \%$ prefer foreign rice to local rice. The result of the double hurdle model showed that marital status, age of the household head, education of the household head, household size, price of rice, and the quality of rice significantly influenced the preference decision of the household while marital status, age, household size, monthly income, and quality of rice significantly influenced the expenditure decision of the household in the study area. The major reasons for rice preference by the respondents were absence of foreign matter (impurities such as stones), shape of grain, stickiness after cooking, rate of breakage and cleanliness of the rice. The study recommended that modern processing techniques, which improve on locally produced rice will enable it compete favourable with imported ones; thereby increasing consumption of local rice consumption in the country.
\end{abstract}

Key words: double hurdle, local rice, consumption

\section{INTRODUCTION}

Rice is one of the staple foods in Nigeria and could be found in the homes of the higher class, the middle-income earner and the poor. According to FAO (2017), Nigeria is Africa's leading producer of rice, consumer of rice, and incidentally one of the largest rice importers in the world. It is an essential cash crop, with large number of subsistence farmers who sell a large portion of their produce yearly. The average Nigerian consumes $24.8 \mathrm{~kg}$ of rice per year, representing 9 per cent of annual calorie intake International Rice Research Institute (IRRI, 2004). Due to its increasing contribution to the per capita calorie consumption of Nigerians, the demand for rice has been increasing at a much faster rate than domestic production and more than in any other African countries since mid-1970s (FAO, 2004). Rice generates more income for Nigerian farmers than any other cash crop in the country (FAO, 2017). In 2008, Nigeria produced approximately 2 million Metric Tonnes (MT) of milled rice and imported roughly 3 million metric tons, including the estimated 800,000 metric tons that is suspected to enter the country illegally on an annual basis. Report has it that between 2005 and 2015, Nigeria's monthly import bill rose from \$148 billion to $\$ 917$ billion. Over the years, the country has depended so much on imports to fill the local supply gap which arose due to inability of local producers to meet demand. The consumption of rice in Nigeria has grown rapidly over the past decade and is currently at an all-time high of 7 million MT while local production by farmers has 
been projected to reach 2.7 million MT in 2017 USDA, (2017). This presently leaves a gap of 4.3 million MT to be cushioned by importation. This indicates that the country has only 49 per cent selfsufficiency level in rice production. Studies have shown that imported rice cleanliness is the overwhelming factor behind the expansion of imported rice consumption in Nigeria at the expense of local rice development, in spite of the high tariff barrier. However, when prices and grain appearance are put aside, customers acknowledged the attractiveness of Nigerian rice organoleptic properties -an asset that cannot be properly exploited in the current situation due to the poor performance of the rice commodity chain in terms of quality management. These constraints tend to turn rice retailer away from the local rice marketing in favour of the imported rice (Osareti et al., 2007 Lancon et al., 2003; Akande, 2001). On the other hand, Ogazi (2009) opined that Nigerian local rice has failed to meet the demand of her teeming population not only in quantity but also in quality, largely due to neglect of the agricultural sector by successive governments. Bamidele et al., (2010) noted that the problem of Nigeria's dependence on imported rice is more so as the share of the imported rice in the Nigerian food market is far above that of the domestically produced rice. Rice imports have affected the domestic production and marketing of Nigeria's local rice.

The non-competitiveness could also be as a result of poor processing resulting in a final product with a high percentage of broken grains and debris (FAO, 2004). The study is therefore, focused on the preference and the amount spent on local rice by the consumer. It is expected that the outcome of this study would among other things; identify the factors that influenced the consumer preference and the amount spent on local rice in the study area. This information would assist policy makers and planners in understanding the present state of local rice consumption in the area with the purpose of evolving policies and programmes that will boost production, distribution and consumption and thus reduce Nigeria's reliance on importation to meet local demand.

\section{MATERIALS AND METHODS}

The study was carried out in Ikwuano Local Government Area (LGA) of Abia State, Nigeria. There are 4 clans in Ikwuano Local Government Area and 28 autonomous communities. The four clans were selected for the study. The simple random sampling technique was used in selecting four (4) autonomous communities from each of the clans. A list of households in each of the autonomous communities formed the sampling frame. The systematic sampling technique was then used to select ten (10) respondents from each of the four randomly selected autonomous communities giving a total of one hundred and sixty (160) respondents. The respondents were also stratified into low, medium, and high income earners homogenous classes. Out of the 160 questionnaires issued to the respondents 154 were returned while 150 were found valid to be used for the study.

\section{Specification of the Double Hurdle Model for Consumption}

Double-hurdle model was used to analyse household consumption of local rice. However, given the existence of zero observations on the dependent variable, the Tobit model could also have been considered. However, the Tobit model by itself has many drawbacks. In the Tobit specification, first, all zero observed amount spent are interpreted as corner solutions. Second, it is based on a restrictive assumption that both preference and the expenditure decision given the decision to participate are determined by the same set of variables which implies that a variable that increases the probability of participation also increases the amount spent on local rice (Wooldridge, 2002). Applying this model imposes the assumption that zero consumption is attributable to economic factors alone. Therefore, as an alternative approach, the consumption of households could be modeled in a two-stage (double hurdle) process. The double-hurdle model, originally formulated by Cragg (1971), assumes that households make two decisions with regard to purchasing an item, each of which is determined by a different set of explanatory variables. In order to observe a positive level of consumption, two separate hurdles must be passed. This method provides a general approach to modelling participation and expenditure decision as two-stage decision process. Although the approach was widely used in the empirical studies of consumer demand and agricultural technology adoption (Simtowe and Zeller, 2007; Getachew et al., 2009), it has also been used to study consumption decisions (Akinbode and Dipeolu, 2012). Therefore, it has the advantage that it permits the joint modeling of the decision to participate and the expenditure decision (the amount spent) on a particular commodity (Yen and Huang, 1996). In this model, individuals should pass two-step decision processes; first, they have to decide to participate in local rice market and then they need to decide the amount of their income to be spent on local rice at a prevailing market price. Therefore, if we observe a positive amount spent by an individual on local rice, the understanding is that he/she has completed a two-stage process. In other words, if zero amount is observed to be spent by an individual, it is either because of the preference decision (not participating), or the expenditure decision (not spending any amount), or both. The model works under the assumption that there exist 
Onya, S.C., Okezie, C.A. and Ejiba, I.V.

two latent variables: $\gamma_{1}^{* *}$ related with the individual's decision to participate in the local rice consumption and $\gamma_{2}^{* *}$ with his decision on the amount to be spent on the commodity (Akinbode and Dipeolu, 2012). These latent variables are expressed as linear functions of the first and second hurdle regressors, $X_{1}$ and $X_{2}$, respectively:

$\gamma_{1}^{* *}=\chi_{1 \beta_{1}}+\mu_{1} \ldots \ldots \ldots \ldots \ldots \ldots \ldots$. Preference

Decision (local or foreign rice).

$\gamma_{2}^{* *}=\chi_{2 \beta_{2}}+\mu_{2} \ldots \ldots \ldots \ldots \ldots \ldots \ldots \ldots$ Expenditure

Decision (local or foreign rice)

where $X_{1}$ represents the regressors used to explain the preference decision in equation (1) and $X_{2}$ those used to explain the expenditure decision in equation (2). Suppose that an index variable $\gamma_{1}^{*}$ is expressed as $\gamma_{1}^{*}=1$ if the individual prefers local rice and $\gamma_{1}^{*}$ $=0$, otherwise, then we have: $\gamma_{1}^{*}=1$ if $\gamma_{1}^{* *}>0 \quad \gamma_{1}^{*}$ $=0$, if otherwise Assuming that the error term $\mu_{1}$ in equation (1) is normally distributed, the first hurdle corresponds to a probit model. Similarly, turning to the expenditure equation, provided that the first hurdle was cleared, $\gamma_{2}^{*}$ can also be generated as:

$$
\begin{gathered}
\gamma_{2}^{*}=\gamma_{2}^{* *}, \text { if } \gamma_{2}^{* *}>0, \text { and } \\
\gamma_{2}^{* *}=0, \text { ifotherwise }
\end{gathered}
$$

This second hurdle takes the form of truncated regression and is capable of generating zero levels of expenditure, independent of the first hurdle. Finally, the observed (actual) amount spent, $\gamma$, is determined by the interaction of both hurdles, that is: $\gamma=\gamma_{1}^{*} \gamma_{2}^{*}$

The double-hurdle model specification assumes a bivariate normal distribution $(\mathrm{BVN})$ of latent variables given as:

$\left(\frac{\overline{\mu_{l}}}{v}\right) \sim B V N\left[0,\left(\begin{array}{cc}\sigma_{\mu}^{2} & \rho \sigma_{\mu} \\ \rho \sigma_{\mu} & 1\end{array}\right)\right]$

The explanatory variables of equation(s) (1) and (2) are sex $($ male $=1$, otherwise $=0)$, marital status (married $=1$, otherwise $=0$ ), age (years), education of household head (years), education of spouse (years), household size (number), household

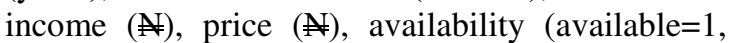
otherwise $=0$ ), quality (high $=1$, otherwise $=0$ ).

\section{RESULTS AND DISCUSSION \\ Socioeconomic Profile of the Households in the Study Area}

The socioeconomic profile of the respondents is presented in Table 1. The gender distribution of the respondents showed that majority $(64 \%)$ were female while $36 \%$ were male. This could be due to the fact that in traditional African society, females are always seen as those in charge of the household kitchen and as such most of the questionnaires and interviews were transferred to their wives by the male member of the household. This conforms to the assumption that the decision of household food consumption is mostly done by the female. The distribution of the respondents according to their marital status showed that majority $(76 \%)$ were married, while $12 \%$ were single and divorced respectively. Mostly, consumption decisions are usually made by household heads and marital status inform the preference and expenditure decisions of the households The age distribution of the respondents showed that $32 \%$ were between the age of 26-35 years, $40 \%$ were between the age range of $36-45$ years, $22.67 \%$ were between the age range of 46-55 years while $5.33 \%$ were between the age range of 56-65 years. The mean age of the respondents was 41.09 years with a standard deviation of 9.31. The mean age of 41.09 years showed that majority of the respondents were matured enough to make an informed decision on their preference and expenditure on rice in the study area. The distribution of the respondents according to their level of education showed that majority (40\%) had secondary education, 32\% had primary education, $24 \%$ had tertiary education while $4 \%$ had no formal education. The mean years of education of the household head was 10.56 years with a standard deviation of 2.05 The distribution of the respondents according to the educational level of spouse showed that majority $(40 \%)$ of the respondents had primary education, $28 \%$ had secondary education, $20 \%$ had tertiary education while $12 \%$ had no formal education. The mean years spent in school of the spouse was 8.69 years with a standard deviation of 5.77. This implies that, $88 \%$ of the spouse had formal education in the study area. The distribution of the respondents according to their household size showed that majority $(53.33 \%)$ of the respondents had household size of between 4-6 persons, $22.67 \%$ had between 1-3 persons, $18.67 \%$ had between 7-9 persons while $1.33 \%$ had between $10-12$ persons. The average household size was 5.6 (about 6 persons) with a mean deviation of 1.73. This implies that majority of the respondents had a moderate household size. The distribution of the respondents based on their monthly income showed that majority (52\%) earn between 20,000-40,000, $28 \%$ earn between $\$ 40,001-60,000,16 \%$ earn between $¥ 60,001-80,000$ while $4 \%$ earn between \# 80,001-100,000. The distribution of the respondents based on their preference for rice showed that majority (56\%) of the respondents prefer foreign rice to local rice while $44 \%$ of the respondents prefer local rice to foreign rice. The reason for the poor preference is not far-fetched as local rice has more defects vis-à-vis it's processing than foreign rice. 
Table 1: Socioeconomic Profile of the Respondents

\begin{tabular}{|c|c|c|c|c|}
\hline 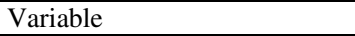 & Frequency & Percentage & Mean & Mean Deviation \\
\hline \multicolumn{5}{|l|}{ Sex (HH) } \\
\hline Male & 54 & 36.00 & & \\
\hline Female & 96 & 64.00 & & \\
\hline \multicolumn{5}{|l|}{ Marital Status } \\
\hline Single & 18 & 12.00 & & \\
\hline Married & 114 & 76.00 & & \\
\hline Divorced & 18 & 12.00 & & \\
\hline Age $(\mathrm{HH})$ & & & \multirow[t]{5}{*}{41.09} & \multirow[t]{5}{*}{9.31} \\
\hline $26-35$ & 48 & 32 & & \\
\hline $36-45$ & 60 & 40 & & \\
\hline $46-55$ & 38 & 22.67 & & \\
\hline $56-65$ & 8 & 5.33 & & \\
\hline Level of Education $(\mathrm{HH})$ & & & \multirow[t]{5}{*}{10.56} & \multirow[t]{5}{*}{2.05} \\
\hline No formal Education & 18 & 4 & & \\
\hline Primary & 60 & 32 & & \\
\hline Secondary & 42 & 40 & & \\
\hline Tertiary & 30 & 24 & & \\
\hline Level of Education Of Spouse & & & \multirow[t]{5}{*}{8.96} & \multirow[t]{5}{*}{5.77} \\
\hline No formal Education & 18 & 12.00 & & \\
\hline Primary & 60 & 40.00 & & \\
\hline Secondary & 42 & 28.00 & & \\
\hline Tertiary & 30 & 20.00 & & \\
\hline Household size & & & \multirow[t]{6}{*}{5.6} & \multirow[t]{6}{*}{1.73} \\
\hline $1-3$ & 34 & 22.67 & & \\
\hline $4-6$ & 86 & 53.33 & & \\
\hline $7-9$ & 28 & 18.67 & & \\
\hline $10-12$ & 2 & 1.33 & & \\
\hline \multicolumn{3}{|l|}{ Monthly Income (N) } & & \\
\hline $20,000-40,000$ & 78 & 52.00 & \multirow[t]{4}{*}{46451.39} & \multirow[t]{4}{*}{9267.67} \\
\hline $40,001-60,000$ & 42 & 28.00 & & \\
\hline $60,001-80,000$ & 24 & 16.00 & & \\
\hline $80,001-100,000$ & 6 & 4.00 & & \\
\hline \multicolumn{5}{|l|}{ Preference for Rice } \\
\hline Foreign & 84 & 56.00 & & \\
\hline Local & 66 & 44.00 & & \\
\hline
\end{tabular}

Source: Field Survey, 2017 Note: HH: Household Head.

Table 2: Estimated Result of the Double Hurdle Model for Consumption of Rice

\begin{tabular}{|c|c|c|c|c|c|c|}
\hline \multirow[t]{2}{*}{ Variables } & \multicolumn{3}{|c|}{ First Hurdle: Preference Decision } & \multicolumn{3}{|c|}{ Second Hurdle: Expenditure Decision } \\
\hline & Coefficient & Std Error & t-value & Coefficient & Std Error & t-value \\
\hline Constant & 9.5385 & 3.0769 & $3.10 * * *$ & 7572.23 & 3923.44 & $1.93^{*}$ \\
\hline Gender & -.0099 & .4950 & -0.02 & -1470.4 & 1441.57 & -1.02 \\
\hline Marital Status & 2.1636 & 1.0764 & $2.01 *$ & 2064.2 & 10321.1 & $2.00 *$ \\
\hline Age & -.0669 & .0336 & $-1.99 *$ & -126.97 & 61.3382 & $-2.07 *$ \\
\hline Education of $\mathrm{HH}$ & -.5542 & .2053 & $-2.70 * * *$ & -234.26 & 344.50 & -0.68 \\
\hline $\begin{array}{l}\text { Education of } \\
\text { Spouse }\end{array}$ & .0124 & .0591 & 0.21 & -105.36 & 96.6606 & -1.09 \\
\hline Household Size & .5258 & .2129 & $2.47 * *$ & 1430.2 & 334.16 & $4.28^{* * *}$ \\
\hline $\begin{array}{l}\text { Household } \\
\text { Income }\end{array}$ & .000014 & .000014 & 1.00 & -.01844 & .0069 & $-2.66 * * *$ \\
\hline Price of Rice & -.0945 & .0397 & $-2.38 * *$ & 23456 & 14940.13 & 1.57 \\
\hline Availability & .00344 & .0044 & 0.79 & .04067 & .04729 & 0.86 \\
\hline Quality of Rice & -1.5681 & .4227 & $-3.71 * * *$ & 2.8764 & 1.2452 & $2.31 * *$ \\
\hline Pseudo $\mathrm{R}^{2}$ & 0.3716 & & & 0.0216 & & \\
\hline Log Likelihood & -32.6300 & & & -513.008 & & \\
\hline
\end{tabular}

This is corroborated by the findings of Daramola (2005); FAO (2004); Bamidele et al., (2010) and Alfred and Adekayode (2013) who noted that local rice is non-competitive with the foreign or imported rice due to high cost of production and poor processing technique. Alfred and Adekayode (2013) therefore, noted that if farmers could adopt more efficient methods of processing, the price of local rice can compete favourably with imported rice.
The Preference and Expenditure Decision on Local Rice of Households

The preference and expenditure decision on local rice of households is presented in Table 2. The coefficient of marital status of the respondents was positive and significant at $10 \%$ level for preference decision of the households. This implies that married people tend to prefer local rice than foreign rice. 
Table 3: Reasons for Rice Preference by the Respondents

\begin{tabular}{llll}
\hline Reason & Frequency & Percentage & Ranking \\
\hline Taste & 52 & 34.67 & $6^{\text {th }}$ \\
Price & 49 & 32.67 & $7^{\text {th }}$ \\
Absence of Foreign & 121 & 80.67 & $1^{\text {st }}$ \\
Matter & & & \\
ase of Cooking & 31 & 20.67 & $10^{\text {th }}$ \\
Good Aroma & 45 & 30.00 & $8^{\text {th }}$ \\
Shape of Grain & 112 & 74.67 & $2^{\text {nd }}$ \\
Cleanness & 66 & 44.00 & $5^{\text {th }}$ \\
Rate of Breakage & 92 & 61.33 & $4^{\text {th }}$ \\
Stickiness After & 96 & 64.00 & $3^{\text {rd }}$ \\
Cooking & & & \\
Readily Available & 39 & 26.00 & $9^{\text {th }}$ \\
\hline Source: Field Survey, $2017 *$ multiple responses &
\end{tabular}

This may not be unconnected with the increased financial burden associated with marriage. The coefficient of marital status of the respondents was positive and significant at $10 \%$ for the expenditure decision of the household heads. By implication, married people tend to spend more in local rice than unmarried people do. The coefficient of age of the respondents was negative and significant at $10 \%$ level for both the preference and expenditure decision of the households. This implies that as one ages his preference and as well as amount spent on local rice reduces. This could be because elderly people have less energy to go through the rigorous process of selecting, removing impurities and sieving the rice and as such would prefer foreign rice with no impurities to remove and less stress in cooking. Danso-Abbeam et al., (2014) however noted that the negative relationship is contrary to apriori expectation because as the age of the respondents increase one will expect their preference for foreign rice to decline because older people are likely to resort to traditional staple foods. The coefficient of education of the respondents was negative and significant at 5\% level for the preference decision of the household but not significant for the amount spent on local rice. This implies that educated people prefer foreign rice to local rice. This could be as a result of the high quality of the foreign rice in terms of neatness, stone free and not necessarily because of the nutritional quality. This is in line with the findings of Ayinde et al., (2013) and Ogundele (2014) who observed a negative relationship between education of the household head and consumer preference for local rice. The coefficient of household size was positive and significant at $5 \%$ and $1 \%$ level for the preference and expenditure decision of the household head respectively. This implies that families with larger household size prefer local rice and tend to spend more on it than one with small household size. This could be because local rice is cheaper in the market than foreign one and with large household size there will be more mouth to feed and the rational decision will be to go for the cheaper rice. This is in agreement with the work of Ayinde et al. (2013) who noted that for every percentage increase in the household size by one person, there is an increase in household expenditure of $42.2 \%$ on local rice. The coefficient of the monthly income of the respondents w2424as positive but not significant for the preference decision; and negative and significant at $1 \%$ for the expenditure decision of the household head. The inverse relationship between the monthly income of the respondents and the amount spent on local rice is as a result of the fact that people tend to go for quality as their income go up and as such may not spent much on local rice because of the poor quality of it. This is contrary with the findings of Ayinde et al. (2013) who noted that for every $\$ 1$ percentage increase in the household monthly income, expenditure on Ofada rice will increase by 0.681 kobo. The coefficient of price was negative and significant at $5 \%$ level for the preference decision of the household heads. Given the option of foreign rice and local rice at the same price, the consumer will prefer the foreign rice, so as price of local rice goes up, the preference for it goes down. This corroborates the finding of Ogundele (2014) who found a negative relationship between price of local rice and consumer preference. In other words, as the prices of foreign rice increases, households tend to reduce their consumption of foreign rice by resorting to consumption of low priced local rice or other food items as substitute for foreign rice. This finding lends credence to that of Oyinbo et al. (2013) and Odusina (2008) who found that the high price of imported rice is discouraging its consumption. The coefficient of quality was negative, significant at $1 \%$ for the preference decision of the household heads, positive, and significant at $5 \%$ for the expenditure decision of the household head. This implies that if the quality of local rice is poor the people tend to prefer foreign rice to local rice, and if the quality of local rice is high they tend to spend more on local rice.

Factors Affecting Consumer Preference for Rice The factors affecting consumer preference for rice in the study area is presented in Table 3 . Table 3 showed that the major reasons for rice preference among the respondents were absence of foreign matter (impurities), shape of grain, stickiness after cooking, rate of breakage and cleanliness of the rice. Other minor reasons as identified by the respondents were taste, price of rice, aroma, availability and ease of cooking. This implies that households will always prefer foreign rice to local rice if the price of the foreign rice is affordable to them, as foreign rice has been adjudged to have good quality with respect to majority of the factors that determine preference decision of the households. 


\section{CONCLUSION}

The study analysed the preference and expenditure decision on local rice consumption of households in Ikwuano LGA of Abia State. From the result, the respondents preferred consuming foreign rice to local rice probably based on the absence of foreign matter (impurities), shape of the grains and cleanliness of the rice. The consumer preference decision was influenced by marital status, age of the household head, education of the household head, household size, price of rice, and the quality of rice while marital status, age, household size, monthly income, and quality of rice significantly influenced expenditure decision on local rice. The major reasons for rice preference by the respondents were absence of foreign matter, shape of grain, stickiness after cooking, rate of breakage and cleanliness of the rice. It is obvious from the study that cleanliness of local rice is one major way of promoting local rice consumption; as such more attention will be required right from the harvesting stage to the milling stage. Modern processing techniques intended to improve the quality of local rice by reducing the content of foreign matter will increase the competitive nature of local rice to compete favourably with imported ones. In addition, to stimulate the rise in demand for locally processed rice and to improve the welfare of local farmers, the current ban on imported rice should be sustained to pave the way for the development of the locally produced rice in the country.

\section{REFERENCES}

Akande T. (2001). Overview of the Nigeria Rice economy. The Nigerian Institute Social and Economic Research (NISER).

Akinbode S.O. and Dipeolu A.O. (2012). Double Hurdle Model of Fresh Fish Consumption among Urban Households in South-West Nigeria. Current Research Journal of Social Sciences, 4 (6), 431-439

Alfred S.D.Y. and Adekayode A.B. (2014). Consumers' attitude towards local rice production and consumption in Ondo State, Nigeria, Journal of Agricultural extension and rural development Vol. 6 (7), 242-248

Ayinde I., Kareem R., Hodefe O.J. and Bakare H. (2013). Consumption Pattern of Ofada Rice among Civil Servants in Abeokuta Metropolis of Ogun State, NigeriaJournal of Biology, Agriculture and Healthcare Vol. 3 (6), 106-112

Bamidele F.S., Abayomi O.O and Esther O.A. (2010). Economic Analysis of Rice Consumption Patterns in Nigeria. Journal of Agricultural Science and Technology, 12, $1-11$.

Cragg J., (1971). Some statistical models for limited dependent variables with applications to the demand for durable goods. Econometrica, 39 (2), 829-844.

Danso-Abbeam G., Ahmed M. and Baidoo F. (2014). Determinants of Consumer Preference for Local Rice in Tamale Metropolis, Ghana International Journal of Education and Social Science Vol. 1 (2), 114-122.
Daramola A.G. (2005). Government Policies and Competitiveness of Nigerian Rice Economy. A Paper Presented at the Workshop on Rice Policy and Food Security in Sub-Saharan Africa, Organised by WARDA, Cotonou, Republic of Benin

Food and Agricultural Organisation (2017). Nigeria at a Glance

Food and Agricultural Organisation (2004). Marketing Integration, Price Transmission and Import Surges. FAO import Surge Working Paper 6, 1-9

Getachew L., Augustine S., Wilfred M., Moti J. and Roberto L. (2009). Household resource endowment and determinants of adoption of drought tolerant maize varieties: Double-hurdle Approach. Contributed paper prepared for presentation at the International Association of Agricultural Economists Conference, Beijing, China, August 1622, (2009).

International Rice Research Institute, (2004). World Rice Statistics. International Rice Research Institute, Manilla, phillipines. ISSN: $1684-5315$.

Lançon F., Erenstein O., Akande S.O., Titilola S.O., Akpokodje G. and Ogundele O.O. (2003). Imported Rice Retailing and Purchasing in Nigeria: A Survey. West Africa Rice Development Association (WARDA), Abidjan, Cote d'Ivoire.

National Population Commission, (2006). Official census figures.NPC, Abuja, Nigeria.

Odusina O.A. (2008). Urban Rice Demand Analysis: A Case Study of Ijebu Ode Township. Middle-East Journal of Scientific Research, 3 (2), 62 - 66.

Ogazi C.G. (2009). Rice Output Supply Response to the Changes in Real Prices in Nigeria: An Autoregressive distributed Lag Model Approach. Journal of Sustainable Development 4 (11), 83-100

Ogundele O. (2014). Factors influencing consumer's preference for local rice in Nigeria. African Journal of marketing Management, Vol 6 (4), pp 49 - 55

Osareti Albert, T. Ebuehi and A. C. Oyewole (2007).Effect of cooking and soaking on Physical characteristics, nutrient composition and sensory evaluation of indigenous and foreign rice varieties in Nigeria. Africa Journal of Biotech, Vol. 6, No. 8 pp. $1016-1020$

Oyinbo O., Omolehin R.A. and Abdulsalam Z. (2013). Household Consumption Preference for Imported and Domestic Rice in Kaduna State, Nigeria: Implication for Rice Quality Improvement Publication of Nasarawa State University, KeffiPAT June, (2013). 9 (1), 29-37

Simtowe F, Zeller M (2007). The impact of access to credit on the adoption of hybrid maize in Malawi: An empirical test of an Agricultural Household Model under credit market failure. AAAE Conference Proceedings (2007), pp. 131-145.

United States Department of Agriculture, (2017). Nigeria Milled rice domestic consumption annual growth rate

Wooldridge J (2002). Econometric Analysis of Cross Section and Panel Data. The MIT Press, Cambridge.

Yen S. and Huang C. (1996). Household Demand for Finfish: A Generalized Double-Hurdle Model, Journal of Agricultural and Resource Economics, Vol. 2 (1), 202-234 